China’s Environmental Policy: A Critical Survey

by

Gregory C. Chow, Princeton University

CEPS Working Paper No. 206

April 2010 


\title{
China’s Environmental Policy: A Critical Survey
}

\author{
Gregory C. Chow \\ Princeton University
}

\begin{abstract}
This paper reviews the basic laws and policies of the Chinese government on environmental problems and discusses the issues in policy implementation, the prospect of solving the environmental problems in the future and some recent successes in the development of alternative energy and in controlling pollution. It also includes two proposals for improving the regulation of industrial pollution in China and for controlling carbon emission in the world.
\end{abstract}

For over three decades China has achieved remarkable success in economic development unmatched in human history. Such a rapid economic development has naturally carried with it considerable damage to the natural environment.

The environmental problems facing China in the course of its economic development were serious. To illustrate, according to a 1998 report of the World Health Organization (WHO), of the ten most polluted cities in the world, seven were found in China. Air pollution was caused by coal combustion that generated sulfur dioxide and soot as two major air pollutants, resulting in the formation of acid rain falling on about $30 \%$ of China's total land area. Industrial boilers and furnaces consume almost half of China's coal and are the largest sources of urban air pollution. The burning of coal for cooking and heating, in many cities, accounts for the rest. Serious water pollution was caused by coal-fired power plants that released mercury into the air later captured by raindrops, and transferred to surface water and groundwater. China's water is polluted also by the disposal of waste. Water beds of several important cities including Beijing and Shanghai are low, causing shortage of supply of well water. Supply of waters from rivers including the Yellow River and the Yangtze River are running short because of diversion to agriculture production and electricity generation along the sources.

Against this background, the Chinese government has been formulating its environmental policies. Ever since the beginning of economic reform initiated in the late 1970s, the government has paid serious attention to environmental problems. It is the purpose of this essay to survey the basic laws and policies of the Chinese government on environmental problems, the degree of success in policy implementation, the prospect of solving the environmental problems in the long run and some recent successes in the development of alternative energy and in controlling pollution. In addition two proposals for improving the regulation of industrial pollution in China and for controlling carbon emission in the world will be suggested. 


\section{Laws and basic policies}

The current World Expo in Shanghai is a show case of the importance that the Chinese government treats the environmental problem, not only in the construction of the facilities for the Expo and of the Chinese Pavalion itself, but also in the pronouncements that have been made by the government on its attention to the protection of the environment.

The Chinese central government has been aware of the environmental problems and has made serious attempts to protect and improve China's environment. As early as 1979, China passed the Environmental Protection Law for trial implementation. The 1982 Constitution included important environmental protection provisions. Article 26 of the Constitution requires that "the state protects and improves the environment in which people live and the ecological environment. It prevents and controls pollution and other public hazards.” There are also provisions in the Constitution on the state's duty to conserve natural resources and wildlife. Based on these provisions a number of special laws have been enacted. These include the Water Pollution Prevention and Control Law of 1984, the Air Pollution Prevention and Control Law of 1987, the Water and Soil Conservation Law of 1991, the Solid Waste Law of 1995, the Energy Conservation Law of 1997 and several important international agreements including the Kyoto and Montreal Protocols. In June 2002, China enacted the Cleaner Production Promotion Law, which established demonstration programs for pollution regulation in ten major Chinese cities, and designated several river valleys as priority areas.

The State Environmental Protection Administration (SEPA) was established in 1998 to disseminate national environmental policy and regulations, collect data and provide technological advice to the State Council on both national and international environmental issues. SEPA was elevated to the Ministry of Environmental Protection in the Spring of 2008 to emphasize its importance and to give it more power

On policy for $\mathrm{CO} 2$ emission, China appears to be more concerned with the problems of air and water pollution since the CO2 emission problem is less urgent for China. President $\mathrm{Hu}$ Jintao stated on Thursday June 7, 2007, during the G8 meetings in Germany the principle of "common but differentiated responsibilities" for developing countries in tackling climate change. "We should work together to make sure the international community upholds the goals and framework established in the United Nations Framework Convention on Climate Change and its Kyoto Protocol [in 1997] and the principle of common but differentiated responsibilities” while developing countries should also carry out "active, practical and effective cooperation...Considering both historical responsibility and current capability, developed countries should take the lead in reducing carbon emission and help developing countries ease and adapt to climate change... For developing countries, achieving economic 
growth and improving the lives of our people are top priorities. At the same time, we also need to make every effort to pursue sustainable development in accordance with our national conditions.”

At the UN sponsored conference on climate change in Copenhagen in January 2009, Premier Wen Jiabao stated that China was determined to do its share but would not subject itself to international inspection, a position opposed by the United States.

From the economic point of view, the protection of environment can be treated as the government's attempt to correct a major market failure. The failure occurs when natural resources available in the environment are underpriced and over utilized because users of resources like air and water often do not pay for the cost of using it. However the role of the Chinese government is broader in scope than simply correcting this market failure. In the Chinese planning system guided by the National Development and Reform Commission targets are set up to reduce the energy/output ratio and the emission/energy ratio.

For example on Friday, May 8 2007, Premier Wen Jiabao made a speech stating that the current macro-control policy must focus on energy conservation and emission reduction in order to develop the economy while protecting the environment. The Chinese government had set a target in the $11^{\text {th }}$ Five-Year Plan of reducing energy consumption for every 10,000 yuan (1,298 U.S. dollars) of GDP by 20 percent by 2010 [or 4 percent per year], while pollutant discharge [presumably measured by an index of quantities of different pollutants] should drop by 10 percent. The National Development and Reform Commission have also set targets for carbon emission.

\section{Two kinds of policy: Regulation and control vs. economic incentives}

From the analytical point of view we can divide the policies for environmental protection into two kinds. The first kind is command and control. For example the US government has specified Corporate Average Fuel Efficiency (CAFÉ) standards for automobiles sold in 1978 and 2007. For the promotion of the use of alternative technology to produce energy, the government can specify a given share of electricity to be produced by renewable resources. The second kind is to provide economic incentives to save energy or to reduce pollution. An outstanding example is to tax the use of gasoline. Another is to require emitters to pay for permits according to the amount of emission. The permits can be traded among polluters. This is known as a cap and trade scheme.

So far in China the laws are mainly of the regulation and control variety rather than marketbased policies partly because the government has not been able to design a set of appropriate market-based policies, e. g. to estimate the appropriate tax rate. However there have been 
attempts to experiment with such policies. For example, there was an agreement in a December 11-12 2007 cabinet level economic strategy meeting with the US for the two countries to cooperate in introducing emission permits and other economic incentive schemes for controlling pollution. A system of emissions trading for sulfur dioxide, similar to that used in the United States, is being tested in some cites with pilot projects, and may eventually be applied nationwide. The Chinese government will also advance reforms in the pricing of natural gas, water and other resources, raise the tax levied on pollutant discharge, establish a "polluter pays" system and severely punish those who violate the environmental protection laws. Future Chinese environmental initiatives may also include formulating a tax structure beneficial to environmental protection, and granting preferential loans and subsidies to enterprises that construct and operate pollution treatment facilities. The government will also provide incentives to companies that use more energy efficient production facilities and techniques. In recent years China has succeeded in promoting the use of alternative energy and in reducing pollution as will be discussed below.

On March 10, 2010 the National Development and Reform Commission (NDRC) disclosed that it was formulating guidelines for the development of low-carbon economy, and that small scale carbon trading pilot programs will be launched in specific industries and regions.

To archive the target of reducing global green house gas emissions by 50 percent by 2050, investment in low-carbon technologies between 2005 and 2050 will total 1.2 trillion U.S. dollars. China vowed to reduce the intensity of carbon dioxide emissions per unit of GDP in 2020 by 40 to 45 percent compared with the level of 2005 at the Copenhagen conference.

\section{Problem of enforcement}

Although the laws to protect the environment appear well conceived in general and the government has set up an administrative structure for environmental protection, there have been serious failures for central government to achieve its environmental policy objectives. A main reason for the failure is that local governments interested in economic development of their region do not cooperate. It is often to the advantage of local governments to allow pollution to take place illegally in order to promote a higher rate of economic growth and the central government cannot control them. Local government officials benefit from higher levels of output in their region as they receive credits for economic development and sometimes bribes from polluting producers. Given the Chinese system of public land ownership stated in the Constitution, rent seeking local bureaucrats who control the use of land have the tendency to approve the use of land for urban development during their term of office. This has led to overdevelopment of land from the viewpoint of its optimal utilization in the long run and was often an important cause of overheating of the macro-economy, besides creating environmental problems. 
In recent years the Central government recognized this problem and changed its policy for evaluating the performance of local government officials to include the record on environmental protection. The National People's Congress enacted on October 282007 a Law on Conserving Energy by stating that work carried out by local government officials in energy conservation should be integrated into the assessment of their political performance along side with output growth. Such efforts have yielded positive results as will be discussed below.

As an example of failure to meet targets to protect the environment, in April 2007 Premier Wen states: "The challenge of reducing energy consumption and greenhouse gas emissions has proved arduous as China's economy grew 11.1 percent in the first quarter [of 2007] but power consumption surged 14.9 percent... Energy consumption as a fraction of GDP fell only 1.23 percent in 2006, well short of the annual goal of four percent [as stated in the 11th FiveYear Plan of 2006-2010]. “

In the long-run, however, there are reasons for expecting improvement in the implementation of China's environmental policies for three reasons.

1) The strong resolve of the central government as already discussed.

2) The central government has the power to enforce such laws because the operation of an industrial enterprise requires its approval and sometimes even its assistance in the provision of land or credit. In order to protect and improve the environment the government not only can punish the offender but can provide economic incentives for people to act for the economic welfare of the society.

3) There will be a strong positive income effect on the demand for a clean environment. As the Chinese economy gets more developed the demand for cleaner water and air will increase, and the Chinese people can afford to pay for it. In the long run, though not necessarily in the near future, this favorable income effect should more than offset the unfavorable effect of producing a large quantity of output as the experience of the developed economies has demonstrated. The early increase in pollution followed by a reduction in a later stage in the course of economic development is known as the environmental Kuznets curve. This inverted $\mathrm{U}$ shape in the relation between pollution and per capita income is expected to take effect in China in the future.

\section{Recent successes in promoting alternative energy and in controlling pollution}

According to the New York Times, August 25, 2009, although solar energy remains far more expensive to generate than energy from coal, oil, natural gas or even wind the global economic downturn and a decline in European subsidies to buy panels have lowered its price. 
Chinese companies have played a leading role in reducing the price of solar panels by almost half over the previous year. Production of solar panels have increased because production cost in China is lower than in other countries and, since March 2009, the Chinese central and local government have provided heavy subsidies to solar panel manufacturers, including free land, and cash for research and development. State-owned banks are flooding the industry with loans at considerably lower interest rates than available in Europe or the United States. The largest company, Suntech in Wuxi, has become the second largest manufacturer in the world, second only to First Solar of the United States. Many firms in China have entered the market. Some are planning to produce in the US to avoid American protectionist policies against imports from China. Although the production of solar power is increasing, it remains a very small source of energy, with an expected total capacity in 2020 (20,000 megawatts) equal to only half of the output of coal-power plants built in one year.

The successful development of solar panels shows that the Chinese government is capable of identifying an important product to subsidize in order to promote its production for the purpose of economic development and that the Chinese entrepreneurs are ready to take advantage of the government subsidies and the favorable production and marketing conditions in China to expand the production and export of this product. The government's success in promoting the production of clean energy is not limited to solar panels. China has doubled its total wind energy capacity in each of the four years between 2006 and 2009, and was expected to pass the United States in 2009 as the world's largest market for wind power equipment. China is also building considerably more nuclear power plants than the rest of the world combined, and these do not emit carbon dioxide after they are built.

Secondly a success story in the control of air pollution by the use of $\mathrm{SO}_{2}$ scrubbers is reported in a PhD thesis by 徐袁 Xu Yuan at the Woodrow Wilson School of Public and International Affairs of Princeton University. In the $10^{\text {th }}$ Five-Year Plan (2001-2005), China's $\mathrm{SO}_{2}$ emissions went up by $28 \%$ and missed seriously the goal of reducing emission by $10 \%$. However, in the $11^{\text {th }}$ Five-Year Plan (2006-2010), the trend has been reversed. In 2008, China achieved a 9\% reduction of $\mathrm{SO}_{2}$ emissions from the 2005 level, almost reaching the goal of a $10 \%$ by 2010 . The most dramatic change happened at coal power plants: China managed to install $\mathrm{SO}_{2}$ scrubbers at both newly built coal power plants and old ones as retrofits. At the end of 2008, China had $363 \mathrm{GW}_{\mathrm{e}}$ of $\mathrm{SO}_{2}$ scrubbers, or $60 \%$ of the total capacity of coal power generation $\left(601 \mathrm{GW}_{\mathrm{e}}\right)$. By comparison, the ratio at the end of 2005 was only $10 \%$.

The achievement came from the central government's effort in mobilizing both the leaders of local governments and managers of coal power plants. For the former, two measures were taken in the $11^{\text {th }}$ Five-Year Plan: 1) promotion and removal of leaders according to the success in the operation of $\mathrm{SO}_{2}$ scrubbers. 2) using the power to suspend construction of large projects which may affect the environment (including new coal power plants over $200 \mathrm{MW}_{\mathrm{e}}$ ) 
since by law large construction projects require ratification by Ministry of Environmental Protection according to its assessment of the environmental impact of the project. To increase the capacity of supervision by site visits, the total personnel at all government levels increased from 37,934 in 2001 to 52,845 in 2006 , or by $39.3 \%$.

In providing incentives to managers of power plants, the most important policy in the $11^{\text {th }}$ Five-Year Plan for the operation of $\mathrm{SO}_{2}$ scrubbers is called "desulfurized electricity price premium”: After installing $\mathrm{SO}_{2}$ scrubber, a coal power plant is allowed to sell its electricity to the electric grid at a price $15 \mathrm{RMB} / \mathrm{MWh}$ higher than the original price, if the $\mathrm{SO}_{2}$ scrubber is under normal operation; it would be fined $75 \mathrm{RMB} / \mathrm{MWh}$ if its $\mathrm{SO}_{2}$ scrubber were shut down. Although many coal power plants with $\mathrm{SO}_{2}$ scrubbers were receiving the price premium as early as 2004, the penalty and other detailed regulations were not enforced until July 2007.

What are the reasons for success in the control of $\mathrm{SO}_{2}$ emission? Will the same reasons work for controlling air pollution in China in general? There are two conditions favorable for the success in the use of $\mathrm{SO}_{2}$ scrubbers. First, the source of pollution, namely coal power plants, is easy to identify and control. Second, the method of solution by the use of scrubbers is clear cut. Hence it is easy to design policies for the local government officials and for the plant managers to follow. Other cases of air pollution by consumers and by other industrial producers may be more difficult to identify and the methods of solution may not be as straight forward. However, the success in the case of $\mathrm{SO}_{2}$ scrubbers has demonstrated the resolve and the ability of the central government in controlling air pollution. Give its resolve we can expect that the government will try to deal with the more difficult cases even if the effort may be less successful and more time consuming. The government has also learned from this successful experience.

It has been the policy of the Chinese government to promote the development and use of clean energy and to prevent economic production from polluting the environment. I have just cited one successful example in carrying out each of these two policies.

While teaching a graduate course on the economic analysis of environmental problems at the Hong Kong University of Science and Technology in the Spring of 2010, I asked the students to provide examples of successful policies in protecting the environment and in the promoting of clean energy. Some of these examples are cited in the Appendix.

\section{$\underline{\text { 5. Proposals for regulating China's industrial air pollution and for controlling world carbon }}$} emission

On the protection of China's environment and the control of carbon emission in the world many useful ideas are being put forward for the consideration of the Chinese government. 
Here I cite two examples of my own.

First, to improve the regulation of industrial air pollution in China the proposal consists of the following components.

1) Industrial polluters will have to pay for pollution permits issued by the local office of China's Environmental Protection Administration. Any amount of pollution by a polluter, however small, requires having a permit to pollute or emit that amount. The proceeds from the permits will be returned to the local Chinese citizens in some appropriate manner. The number of permits issued (total amount of pollutants discharged) will be determined after consultations with representatives of the local citizens who will be affected by the pollution. The citizens and their representatives presumably balance the harm and benefit of pollution in their area under this proposal.

2) Given the number of permits issued, demand will determine the price per permit. The government will first set an initial price for polluters to purchase the permits. If the price is lower than the equilibrium price, the permits will run out and some polluters need to purchase them from others. If the initial price is too high, there will be unsold permits which the government can sell to late comers at a price lower than the initial price until all permits are sold.

3) Local officers of the State Environmental Administration receive directions from local Chinese citizens through their representatives. Residents in rural areas can be represented by the popularly elected village heads. Urban residents can be represented by their popularly elected representatives of the locality. These representatives will be given responsibility to determine, and will have incentive to enforce, policies to protect the environment.

This proposal echoes two major policy objectives of the Chinese government in economic development, (1) market reform and (2) promotion of a democratic government. Under the proposal market oriented policies to regulate air and water pollution would be formulated democratically. Citizens would participate in the formulation of environmental policies and would thus help to enforce them, rather than protesting against too much pollution as many have done in recent years.

In the implementation of this policy there might be difficulty in monitoring the amount of pollution emitted. This difficulty can be resolved by requiring the polluting factories themselves to submit amount of emission, with false reporting subject to heavy penalty. There might also be inertia on the part of government officials to adopt such a policy as there would be for other policy proposals. Strong resolve on the part of the leaders in the central 
government would be required for this policy to be adopted even if they are convinced of its merits.

I wrote a letter to Premier Wen Jiabao about this proposal and he suggested a Vice Miniister in the Ministry of Environmental Protection to meet with me in Beijing in July 2008 to discuss it. I met with him and several accompanying staff members. The meeting was cordial and friendly and the idea was passed onto these officials for their possible consideration. The control of industrial pollution is a complicated matter. There are other considerations that the officials have to take into account which I may not be aware of.

The second proposal is to regulate carbon emission through a UN resolution. It consists of the following components.

1) The total amount of $\mathrm{CO} 2$ emission in the world is decided as the median of amounts submitted as votes by members of the General Assembly. The median rather than the mean amount would be adopted in order to prevent any member nation from submitting an extreme value to affect the outcome.

2) All countries are required to have permits for the emission of $\mathrm{CO} 2$ not to exceed the amount specified by the permits.

3) Permits are issued by the UN in proportion to size of population under the principle that each world citizen has an equal right to use the atmosphere which is a natural resource. Emitting $\mathrm{CO} 2$ in the atmosphere is an act of utilization of this resource.

4) Emission permits can be traded between any two countries at prices mutually agreed upon.

It is expected that developing countries like China with low level of CO2 emission per capita will obtain financial gain by selling permits. Developed countries like the United States which emit a large amount of $\mathrm{CO} 2$ per capita will need to buy permits. Buying permits is an equitable way for the US to finance the effort of developing countries in limiting $\mathrm{CO} 2$ emission as it has expressed its willingness to do.

China may be attracted by this proposal to make clear to the world that it is not emitting an unduly large share of carbon and that it is willing to play its role in the control of total carbon emission in the world. 


\section{Appendix}

Examples of Policies for the Development of Clean Energy and the Control of Pollution in China cited by Hong Kong University of Science and Technology students

\section{A. Development of clean energy}

In the 11th Five-Year Plan, China decides to increase greatly the production of biomass energy, the supply of electricity from the burning of municipal solid waste and agricultural waste through the construction of power plants to burn these fuels, and to expand the production of solid biomass, bio-ethanol and bio-diesel. It includes targets to achieve 5 million $\mathrm{kW}$ of grid inter-connected wind power and 5.5 million $\mathrm{kW}$ of grid inter-connected electricity from biomass combustion.

Current efforts to offset coal consumption include the development of natural gas and coalbed methane infrastructure, increasing the number of combined heat and power plants, adding approximately 3,000 megawatts (MW) of hydropower annually, and developing renewable energy resources such as wind and photovoltaics for electricity generation.

For China's electricity generation, renewable sources of energy (including hydroelectricity) accounted for $18.6 \%$ in 2001, second to coal. With assistance from the United Nations and the United States, China hopes to embark on a multi-million dollar renewable energy strategy to combat pollution.

China has established a National Working Group for Dealing with Climate Change (国家应对气候变化策略小组) since 1990, and the group became National Leading Group for Dealing with Climate Change ( 国家应对气候变化领导小组) directed by the Premier in 2007. This group has been devoted to fostering the Clean Development Mechanism (CDM), which specially emphasizes the utilization of renewable energy under an emission trade framework.

China has made a great effort on hydropower. The construction of The Three Gorges Dam was started on 1994 and is expected to be fully operated around 2011. It is the world largest hydroelectric power station. According to BP Statistical Review - Full Report 2009, the annual hydroelectric energy produced in China in 2008 was 585.2TWh.

According to China's National Climate Change Program, China is promoting the development of bio-energy. There were more than 17 million household biogas digesters that generate 6,500 million cubic meters of biogas annually. The installed capacity of biomass generation is about $2 \mathrm{GW}$, among which sugar-cane fired power capacity is about $1.7 \mathrm{GW}$ and 
landfill-powered 0.2GW. Production capacity of ethanol fuel based on crops was 1.02 million tons.

The Ministry of Agriculture encourages the use of marsh gas in rural areas. The government also encourages the production of alcohol from various plants and the use of alcohol for energy.

One provision in China's Renewable Energy Law of 2006 encourages continued wind development. It requires power grid companies to buy all output of local registered renewable energy producers and aims for $70 \%$ of China's wind turbines to be produced locally. Provincial governments have also incorporated targets for wind power generation capacity in their five-year plans.

China is currently developing carbon capture and storage facilities for its coal plants. In Nov 2009, U.S and China established a renewable energy partnership. Besides the bio-fuel, solar and wind technologies to be developed, the two countries will also focus on modernizing the electrical grid with new transmission lines and smart grid technology.

From 2001 Dongfeng Automobile Co. was asked to develop a new type of electric bus for the Beijing 2008 Olympics. The company worked really hard on this project. Although it failed to carry out a perfect production due to the speed problem and only 40 their buses were used during the Olympic, the new technology is applicable for family-size vehicles. The remaining problem is to reduce the cost of production.

In the development of natural gas, a number of LNG (Liquefied Natural Gas) stations have been built. The government is also planning to increase nature gas import and building many LNG receiver stations around the coastline. LNG application courses are held at the universities.

\section{B. Environmental protection}

The Chinese government has succeeded in forbidding the use of plastic bags. Now China is consuming and producing hundreds of billions fewer plastic bags, with many women taking a cloth bag for shopping. 